\title{
Worse prognosis in breast cancer patients can be predicted by immunohistochemical analysis of positive MMP-2 and negative estrogen and progesterone receptors
}

\author{
Edneia A. S. Ramos ${ }^{1 \#}$, Camila T. da Silva ${ }^{1 \#}$, Graciele C. M. Manica ${ }^{1}$, Isabela T. Pereira ${ }^{1}$, Liliane M. B. Klassen ${ }^{1}$, \\ Enilze M. S. F. Ribeiro ${ }^{2}$, Iglenir J. Cavalli ${ }^{2}$, Karin Braun-Prado ${ }^{1}$, Rubens S. Lima ${ }^{3}$, Cicero A. Urban ${ }^{3}$, Fabrício F. Costa ${ }^{4}$, \\ Lucia de Noronha ${ }^{5}$, Giseli Klassen ${ }^{1 *}$ \\ ${ }^{1}$ Department of Basic Pathology, Universidade Federal do Paraná (UFPR), Curitiba, PR, Brazil \\ ${ }^{2}$ Department of Genetic, UFPR, Curitiba, PR, Brazil \\ ${ }^{3}$ Hospital Nossa Senhora das Graças, Curitiba, PR, Brazil \\ ${ }^{4}$ Cancer Biology and Epigenomics Program, Ann and Robert Lurie Children's Hospital of Chicago Research Center and Department of Pediatrics, Northwestern University's Feinberg School of Medicine, Chicago, IL, 60614, USA \\ ${ }^{5}$ Department of Experimental Pathology, Pontifícia Universidade Católica do Paraná (PUC-PR), Curitiba, PR, Brazil
}

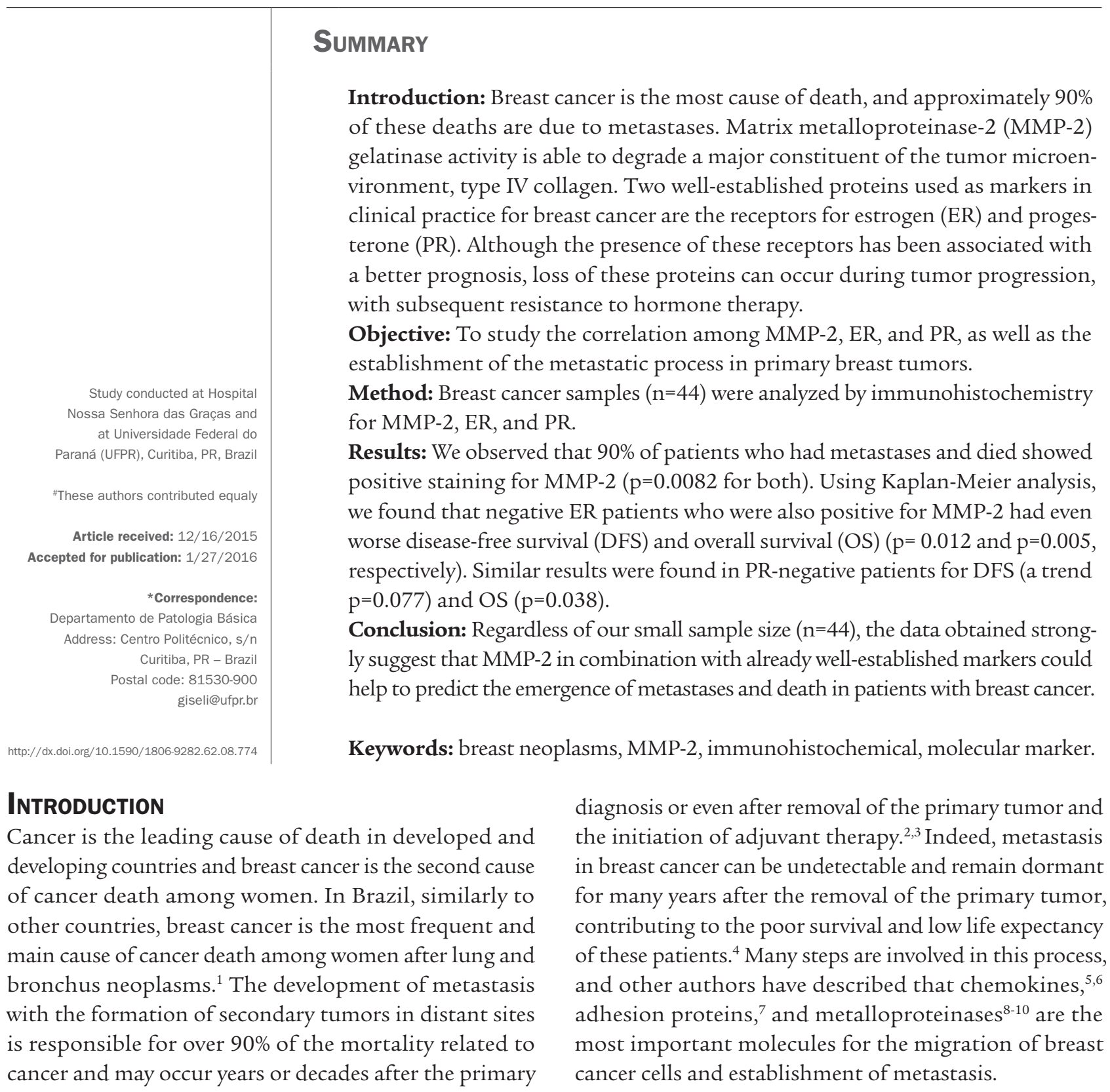


MMPs are involved in normal physiological processes required for development and morphogenesis. A loss of control of MMPs can result in pathological processes including inflammation, angiogenesis, cellular prolifera$\operatorname{tion}^{11,12}$ and are directly involved in the metastatic tumor cell invasion process. ${ }^{9}$ Among them, gelatinase A (MMP-2) is associated with a malignant phenotype, as it is responsible for the degradation of collagen fibers around tumors, thereby releasing these cells from the microenvironment in which they are established. This function is directly involved in the progress of metastasis. ${ }^{9}$ MMP-2 is associated with tumor cell invasion and metastasis in several cancers, including melanoma, ${ }^{13}$ pancreatic, ${ }^{14}$ lung, ${ }^{15}$ ovary, ${ }^{16}$ prostate, and breast ${ }^{17}$ cancer.

Hormone receptors for estrogen (ER) and progesterone (PR) are widely used in the diagnosis and treatment of patients with breast cancer. The main therapeutic approach is endocrine therapy in patients with early and advanced stages of breast cancer and has been used for over five decades. ${ }^{18}$ Authors indicate that both ER and MMP-2 have an important signaling for breast cancer establishment. ${ }^{19}$

Our study evaluated the expression of MMP-2, ER, PR, and HER2 proteins by immunohistochemistry (IHC) in association with the clinical pathological variables of patients as well as the rates of overall survival and disease-free survival in breast cancer. Studies using this approach are scarce, and our results showed that the presence of MMP-2 and absence of ER and PR in primary breast tumors confer susceptibility to metastasis and the consequent death of patients. The inclusion of MMP-2 as a molecular marker could ultimately help in characterizing the disease and guiding the treatment of patients with breast cancer.

\section{Method}

\section{Patients}

In this study, breast cancer tumors from patients embedded in paraffin $(n=44)$ were used for the immunohistochemistry analysis. The samples were obtained from patients undergoing surgery for the removal of the primary tumor at Nossa Senhora das Graças Hospital, Curitiba, Paraná state, Brazil. All patients signed an informed consent for the retention and analysis of tissues for research purposes according to the Ethics Committee. The age of the patients ranged from 27 to 84 years old (average $57.8 \pm 14.7$ ). The histological types included invasive ductal carcinoma (IDC 77\%) and invasive lobular carcinoma (ILC 23\%). The histological grade (SBR) was determined according to the Bloom-Richardson criteria. TNM stage was determined according to the classification of the World Health Organization (WHO). The clinicopathological data of the patients are shown in Table 1.

\section{Ethics Committee}

All patients received and signed a legal consent form releasing their samples for scientific research purposes. The $\mathrm{Na}$ tional Committee of Ethics in Research (CONEP) approved this study under the case number 25000.007020/2003-93. The institutional approval was given by the Ethics Committee on Research with Human Beings at the Federal University of Paraná (UFPR) under the registration number 7220-251/2003 (20/02/2003).

\section{Immunohistochemical analysis (IHC)}

For each sample, a morphological assessment was carried out using a $5 \mu \mathrm{m}$ tissue section stained with hematoxylin-eosin, and the sections were used for MMP-2, ER, and $\mathrm{PR}$ immunostaining using the avidin-biotin immunoperoxidase technique (Polyvalent immunoperoxidase kit; Omnitag, Lipshaw, MI, USA). Endogenous peroxidase was inactivated by incubation with $\mathrm{H}_{2} \mathrm{O}_{2} /$ methanol, and each slide was treated with an antigen unmasking solution (sodium citrate $10 \mathrm{mM}$ plus Tween 20). After blocking, the slides were washed in PBS with $1 \%$ bovine serum albumin and first incubated with the primary antibody and then incubated with a universal secondary biotinylated polyvalent antibody. The primary antibodies used were as follows: polyclonal rabbit anti-MMP-2/72 kDa Collagenase IV (MyBioSource®, dilution 1:400); monoclonal mouse anti-estrogen receptor Clone 1D5 (Dako®); monoclonal mouse anti-progesterone receptor Clone PgR636 (Dako $\left.{ }^{\circledR}\right)$. The chromogenic reaction was developed by incubation with a freshly prepared solution 3-amino-9-ethilcarbazol (AEC) and counterstained with hematoxylin before mounting. The cutoff considered in the analysis of MMP- 2 was 10\% of the cells, as this value is used for the breast cancer markers ER and PR in the medical literature and in clinical practice. For negative controls, instead of the primary antibody, the breast tumor sections were treated with rat $\operatorname{IgG}$ at the same concentration used for all antibodies. HER 2 detection was performed according to the HercepTest ${ }^{\mathrm{TM}}$ protocol (DAKO CYTOMATION code K5204) (Figure 1). HER2 was analyzed in terms of membrane staining on a $0-3+$ scale according to the manufacturer's recommendations. In patients with $2+$ HER 2 expression, an additional chromogenic in situ hybridization test, HER2FISH pharmaDx ${ }^{\mathrm{TM}}$ (DAKO CYTOMATION code K5331), was performed. Two pathologists interpreted the slides in an independent manner. The slides were observed using a motorized Axio Imager Z2 microscope (Carl Zeiss, Jena, DE) equipped with automated scanning VSlide (Metasystem). 
TABLE 1 Clinicopathological features of the 44 patients with primary breast carcinomas according to immunohistochemical status of MMP-2, ER and PR proteins.

Variables Samples MMP-2

(\%)

\begin{tabular}{|c|c|c|c|c|c|c|c|c|c|c|}
\hline & \multirow[t]{2}{*}{ (\%) } & & & & \multicolumn{3}{|l|}{ (ER) } & \multicolumn{2}{|l|}{ (PR) } & \\
\hline \multirow[b]{2}{*}{ Stage } & & Negative & \multicolumn{2}{|l|}{ Positive } & Negative & \multicolumn{2}{|l|}{ Positive } & Negative & \multicolumn{2}{|l|}{ Positive } \\
\hline & & & & & & & & & & \\
\hline 1 & $11(25)$ & $6(55)$ & $5(45)$ & \multirow[t]{3}{*}{0.1172} & $2(18)$ & $9(82)$ & \multirow[t]{3}{*}{0.0263} & $2(18)$ & $9(82)$ & \multirow[t]{3}{*}{0.0641} \\
\hline II & $20(45)$ & $6(30)$ & $14(70)$ & & $4(20)$ & $16(80)$ & & $6(30)$ & $14(70)$ & \\
\hline III/IV & $13(30)$ & $2(15)$ & $11(85)$ & & $8(62)$ & $5(38)$ & & $8(62)$ & $5(38)$ & \\
\hline \multicolumn{11}{|c|}{ Tumor size } \\
\hline pT1 & $10(23)$ & $4(40)$ & $6(60)$ & \multirow[t]{3}{*}{0.5998} & 0 & $10(100)$ & \multirow[t]{3}{*}{0.0112} & $1(10)$ & $9(90)$ & \multirow[t]{3}{*}{0.0994} \\
\hline pT2 & $24(54)$ & $8(33)$ & $16(67)$ & & $10(42)$ & $14(58)$ & & $11(46)$ & $13(54)$ & \\
\hline $\mathrm{pT} 3 / \mathrm{pT} 4$ & $10(23)$ & $2(20)$ & $8(80)$ & & $4(40)$ & $6(60)$ & & $4(40)$ & $6(60)$ & \\
\hline \multicolumn{11}{|l|}{ SBR } \\
\hline I & $11(25)$ & $6(55)$ & $5(45)$ & \multirow[t]{3}{*}{0.1172} & $2(18)$ & $9(82)$ & \multirow[t]{3}{*}{0.0263} & $2(18)$ & $9(82)$ & \multirow[t]{3}{*}{0.0641} \\
\hline II & $20(45)$ & $6(30)$ & $14(70)$ & & $4(20)$ & $16(80)$ & & $6(30)$ & $14(70)$ & \\
\hline III & $13(30)$ & $2(14)$ & $11(86)$ & & $8(62)$ & $5(38)$ & & $8(62)$ & $5(38)$ & \\
\hline \multicolumn{11}{|c|}{ Lymph node status } \\
\hline Positive & $23(52)$ & $7(30)$ & $16(70)$ & \multirow[t]{2}{*}{1.0000} & $9(39)$ & $14(61)$ & \multirow[t]{2}{*}{0.3419} & $9(39)$ & $14(61)$ & \multirow[t]{2}{*}{1.0000} \\
\hline Negative & $21(48)$ & $7(33)$ & $14(67)$ & & $5(24)$ & $16(76)$ & & $12(57)$ & $9(43)$ & \\
\hline \multicolumn{11}{|l|}{ HER-2 } \\
\hline Positive & $13(30)$ & $6(46)$ & $7(54)$ & \multirow[t]{2}{*}{0.2878} & $4(31)$ & $9(69)$ & \multirow[t]{2}{*}{1.0000} & $4(31)$ & $9(69)$ & 0.7385 \\
\hline Negative & $31(70)$ & $8(26)$ & $23(74)$ & & $10(32)$ & $21(68)$ & & $12(39)$ & $19(61)$ & \\
\hline MMP-2 & & & & & & & & & & \\
\hline Positive & $30(68)$ & - & - & & $14(47)$ & $16(53)$ & 0.0015 & $15(50)$ & $15(50)$ & 0.0071 \\
\hline Negative & $14(32)$ & - & - & & 0 & $14(100)$ & & $1(7)$ & $13(93)$ & \\
\hline Progeste & e recepto & PR) & & & & & & & & \\
\hline Positive & $28(64)$ & $13(46)$ & $15(54)$ & 0.0071 & 0 & $28(100)$ & $<0.0001$ & - & - & \\
\hline Negative & $16(36)$ & $1(6)$ & $15(94)$ & & $14(88)$ & $2(12)$ & & - & - & \\
\hline Estrogen & eeptor (EF & & & & & & & & & \\
\hline Positive & $30(68)$ & $14(47)$ & $16(53)$ & 0.0015 & - & - & & $2(6)$ & $28(94)$ & $<0.0001$ \\
\hline Negative & $14(32)$ & 0 & $14(100)$ & & - & - & & $14(100)$ & 0 & \\
\hline Metasta & & & & & & & & & & \\
\hline Positive & $20(43)$ & $2(5)$ & $18(90)$ & 0.0082 & $9(45)$ & $11(55)$ & 0.1121 & $9(45)$ & $11(55)$ & 0.3520 \\
\hline Negative & $24(57)$ & $12(50)$ & $12(50)$ & & $5(21)$ & $19(89)$ & & $7(32)$ & $17(68)$ & \\
\hline Death & & & & & & & & & & \\
\hline Positive & $20(45)$ & $2(10)$ & $18(90)$ & 0.0082 & $10(50)$ & $10(50)$ & 0.0253 & $10(50)$ & $10(50)$ & 0.1196 \\
\hline Negative & $24(55)$ & $12(50)$ & $12(50)$ & & $4(27)$ & $20(73)$ & & $6(33)$ & $18(67)$ & \\
\hline Histolog & type & & & & & & & & & \\
\hline IDC & $34(77)$ & $12(35)$ & $22(65)$ & 0.4618 & $10(29)$ & $24(71)$ & 0.7013 & $10(29)$ & $24(71)$ & 0.1331 \\
\hline ILC & $10(23)$ & $2(20)$ & $8(80)$ & & $4(40)$ & $6(60)$ & & $6(60)$ & $4(40)$ & \\
\hline
\end{tabular}

The bold represents p-value $<0.05$.

MMP-2: matrix metalloproteinase-2; SBR: Scarff-Bloom-Richardson grade; IDC: invasive ductal carcinoma; ILC: invasive lobular carcinoma. 


\section{Statistical analysis}

Statistical analyses were performed using SPSS software (version 18.0, SPSS Inc., Chicago, IL, USA). Associations among the clinical pathological parameters were evaluated using chi-square $(\chi 2)$ or Fisher's exact test. Values were considered significant if $\mathrm{p}<0.05$. For the analysis of survival, time was calculated using the date of disease diagnosis and the occurrence of death or metastasis. Statistical tests by Kaplan-Meier analysis were considered significant if $\mathrm{p}<0.05 .{ }^{20}$ For this analysis, the time interval was 125 months, and the data were collected between 2004 and 2014.

\section{Results}

\section{Immunohistochemical data analyses}

A total of 44 patients, with a mean age of 57.8 years old (range 27 to 84), were enrolled in the study. The clinical data available were stage, tumor size, tumor grade (SBR Scarff-Bloom-Richardson grade), lymph node, metastasis, death and histological type, as well as IHC staining for human epidermal growth factor receptor-2 (HER2), MMP-2, estrogen receptor (ER) and progesterone receptor (PR), as shown in Table 1. Representative slides of breast tumor samples with negative or positive staining are presented in Figure 1.

MMP-2 expression in tumor cells was positive in 68\% of patients (Table 1) but not associated with the factors of stage, tumor size, SBR, lymph node status, HER2 or histological type. In contrast, the presence of MMP-2 was significantly associated with $\mathrm{PR}(\mathrm{p}=0.0071), \mathrm{ER}(\mathrm{p}=0.0015)$, metastasis $(\mathrm{p}=0.0082)$, and death $(\mathrm{p}=0.0082)$.

Expression of ER in tumor cells was found in $68 \%$ of patients (Table 1). The presence of ER was not related to lymph node status, HER2, metastasis or histological type, but there was an association with the variables stage ( $\mathrm{p}=0.0263)$, tumor size $(\mathrm{p}=0.0112)$, SBR $(\mathrm{p}=0.0263)$, MMP$2(\mathrm{p}=0.0015), \operatorname{PR}(\mathrm{p}<0.0001)$, and death $(\mathrm{p}=0.0253)$.

PR-positive tumor cells were found in $64 \%$ of patients (Table 1). The presence of PR was not associated with stage, tumor size, SBR, lymph node status, HER2, metastasis, death or histological type, but an association with MMP-2 ( $\mathrm{p}=0.0071)$ and ER ( $\mathrm{p}<0.0001)$ was observed.

A significant association was found between some of the clinical features and IHC data (Table 1). All patients negative for MMP-2 on IHC were positive for $E R(p=0.0015)$, and $93 \%$ of them were also PR positive $(\mathrm{p}=0.0071)$ (Table $1)$. Ninety percent $(90 \%)$ of the patients that developed metastases and/or died were MMP- 2 positive $(\mathrm{p}=0.0082$, for both analysis). In addition, $94 \%$ of the PR-negative and $100 \%$ of the ER-negative patients were MMP-2-positive $(p=0.0071$ and $p=0.0015$, respectively). These results suggested that these proteins at the same time could be useful for metastasis or death prognosis in breast cancer. To confirm this hypothesis, statistical tests were performed using the Kaplan-Meier method to assess disease-free survival and overall survival in these samples. The patients who showed positive staining for MMP-2 in IHC assays had lower disease-free survival $(\mathrm{p}=0.004)$ (Figure $2 \mathrm{~A})$ and overall survival rates $(\mathrm{p}=0.007)$ (Figure $2 \mathrm{~B}$ ). Interestingly, ER-negative patients who were simultaneously positive for MMP-2 had worse disease-free survival and overall survival rates $(\mathrm{p}=0.012$ and $\mathrm{p}=0.005$, respectively) (Figure $2 \mathrm{C}$ and $\mathrm{D}$, respectively). Similar results were found for the presence of MMP- 2 and the absence of $\mathrm{PR}$ with regard to the trends of disease-free survival $(\mathrm{p}=0.077)$ and overall survival ( $\mathrm{p}=0.038$ ) (Figure $2 \mathrm{E}$ and $\mathrm{F}$, respectively).

\section{Discussion}

Breast cancer is the leading cause of cancer-related death in women worldwide. ${ }^{2}$ Breast cancer metastases may be undetectable and remain dormant for many years after the removal of the primary tumor, emerging years later as an incurable disease. ${ }^{7}$ Although certain molecular markers of proliferative disease are already used in the diagnosis and prognosis of breast cancer, including estrogen receptor (ER), progesterone receptor (PR), and HER2 overexpression, new metastasis markers must be investigated for future use. MMP-2 is a protein associated with metastasis and is extensively studied in several cancers. ${ }^{11-16} \mathrm{ER}$ and MMP-2 have shown a molecular relationship with $\mathrm{E} 2$ or estradiol binding in the $\mathrm{E}$ domains of ER, present in the plasma membrane. This interaction could activate MMP-2 and MMP-9 with subsequent transactivation of EGFR. This mechanism after ER and MMP-2 interaction supports the proliferation and survival of tumor cells in the absence of nuclear ER. ${ }^{21,22}$

In our work, we evaluated the presence of MMP-2 using IHC and its correlation with ER and PR as prognostic factors for metastasis in breast cancer. The ER analyses showed a significant association with factors such as stage, tumor size, SBR grade, MMP-2, PR staining, and death (Table 1), while PR showed significance regarding MMP-2 and ER staining (Table 1). We observed that $90 \%$ of patients who had metastases and died were MMP-2 positive ( $\mathrm{p}=0.0082$ ). Additionally, 94 and 100\% of patients negative for PR or ER, respectively, were positive for MMP-2 (Table 1).

Other works report weak or non significant impact of ER on overall survival in lymph node-negative populations, and suggest that another molecular marker can 


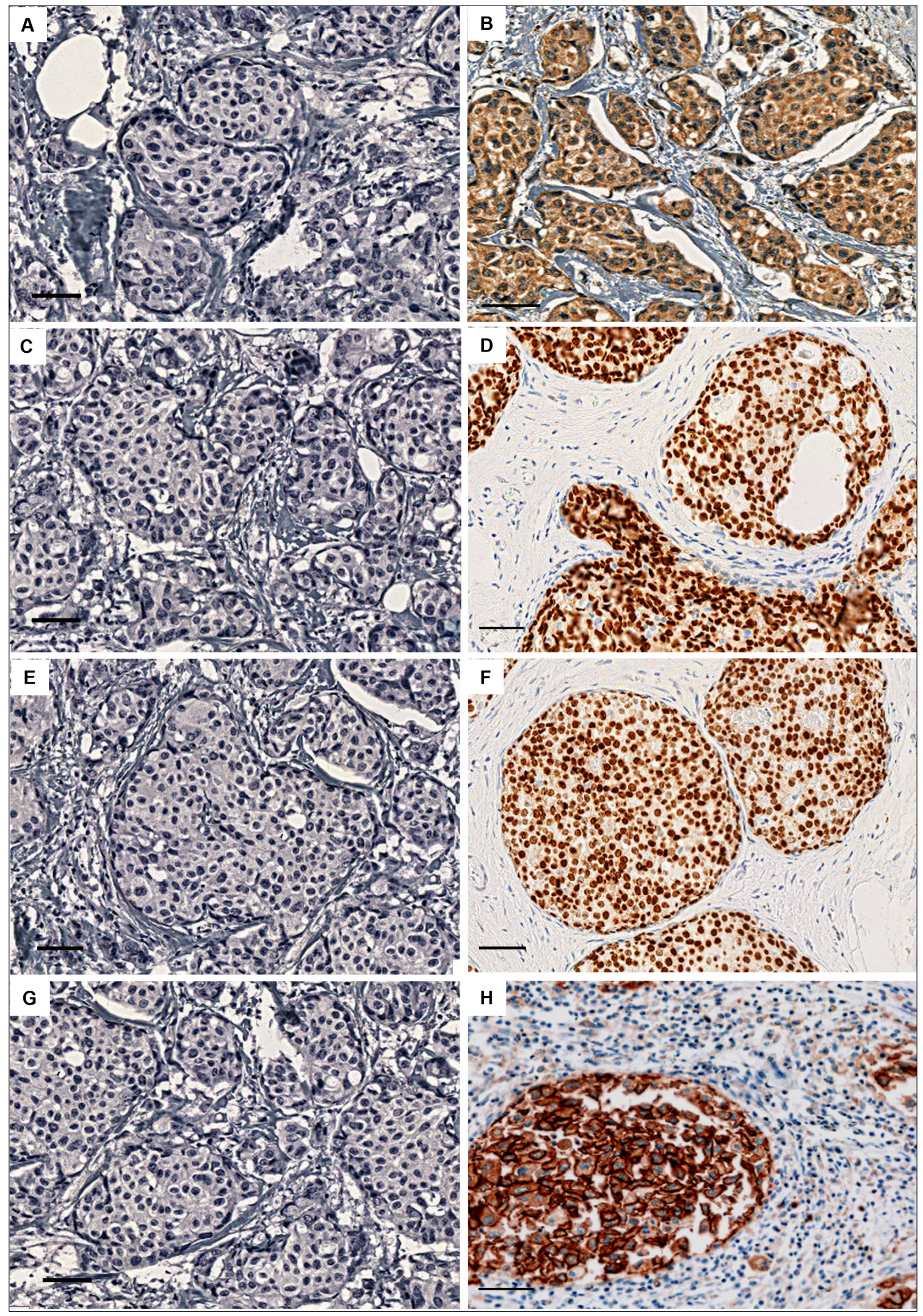

FIGURE 1 Representative examples of immunostaining for the protein markers tested in breast cancer. Negative or positive staining, respectively: MMP-2 (A, B), ER (C, D), PR (E, F), and HER2 (G, H). All the slides were analyzed in $\times 200$ microscope objective and the scale is $50 \mu \mathrm{m}$. 


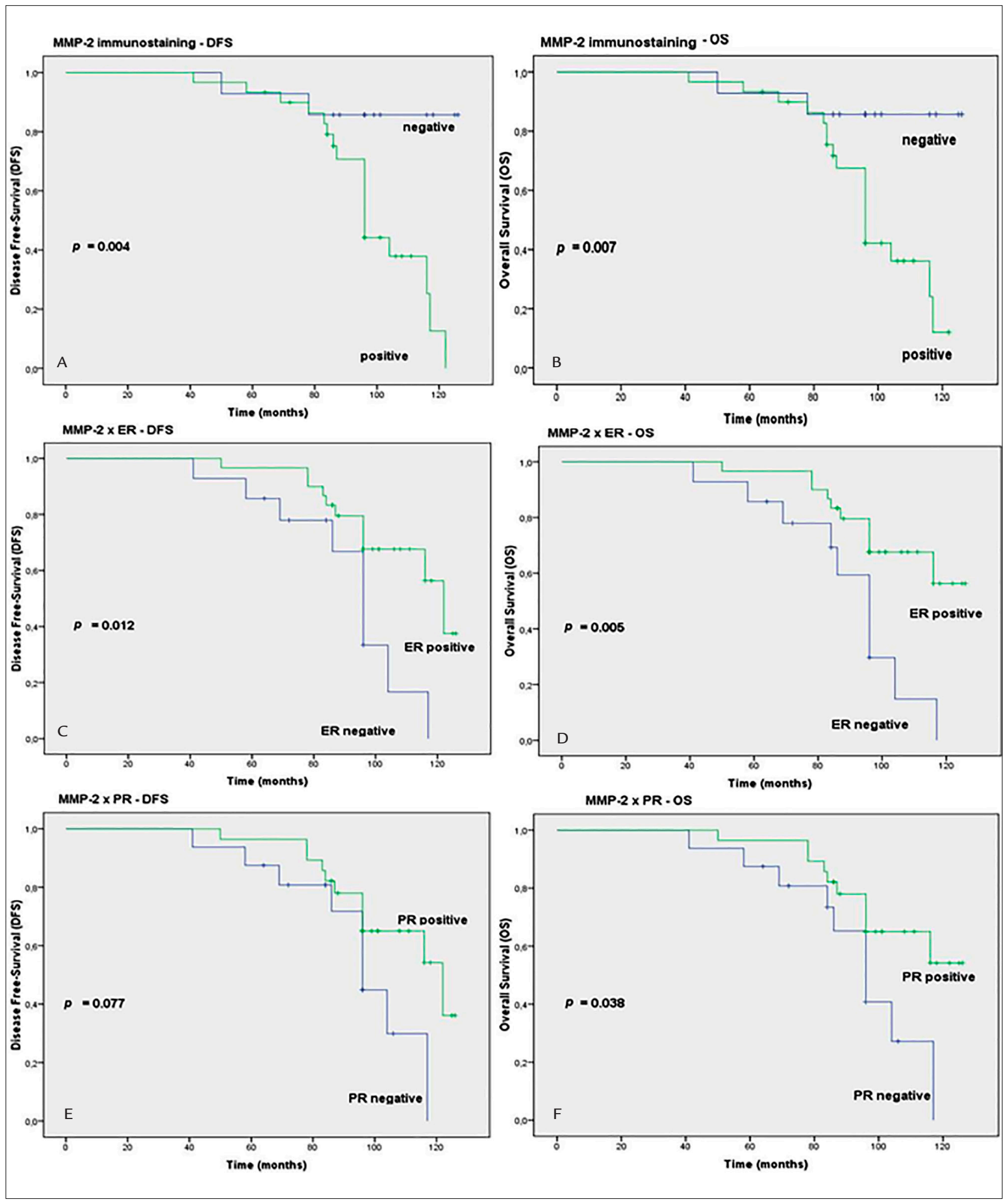

FIGURE 2 Kaplan-Meier curves for disease-free survival (DFS) or overall survival (OS) according to the MMP-2 IHC staining and its correlation with ER and PR. MMP-2 staining and the correlation with (A) DFS and (B) OS are shown. The DFS relationship between MMP-2 positive and ER is shown in (C) and OS relationship between MMP-2 positive and ER is shown in (D). The DFS relationship between MMP-2-positive and $P R$ is shown in (E) and the OS relationship between MMP-2-positive and PR is shown in (F). MMP-2: matrix metalloproteinase-2; ER: estrogen receptor; PR: progesterone receptor. 
better predict survival in breast cancer patients. ${ }^{23}$ Our Brazilian sample does not have ER or PR significantly associated with lymph node, except if MMP-2 is present.

MMP-2 was associated with many aspects of breast cancer prognosis including unique associations with ER/PR tumor status as well as with survival. Our analysis used a Kaplan-Meier test to demonstrate that the presence of MMP-2 was connected to disease-free survival (DFS) $(\mathrm{p}=0.004)$ (Figure $2 \mathrm{~A})$ and overall survival (OS) $(\mathrm{p}=0.007)$. Additionally, both DFS and OS were worse in the presence of MMP-2 and absence of ER $(\mathrm{p}=0.012$ and $\mathrm{p}=0.005$, respectively) (Figure $2 \mathrm{C}$ and $\mathrm{D})$. Ranogajec et al. (2012) studied MMP-2 in breast cancer, and $O S$ was significantly shorter in patients with positive MMP-2. ${ }^{24}$ Recently, Min et al. ${ }^{17}$ correlated the MMP-2 expression pattern with ER and PR, but did not show a correlation with DFS or OS. In another study that used single nucleotide polymorphism analysis (SNP), the authors suggest that MMP-2 can influence patient survival as an independent factor, attenuating the metastatic potential and augmenting survival rates. These authors also suggest that the MMP-2 gene is an important pathway for tumor progression and invasiveness in $\mathrm{ER}+\mathrm{PR}+$ and ER+/PR- samples. ${ }^{12}$ Although based on a smaller sample, our study shows that ER-positive patients did not express MMP-2, while MMP-2-positive patients are ER-negative. A lack of MMP-2 could possibly become an important factor in certain subgroups of breast carcinoma while selecting the adjuvant therapy. Our results support the thesis that MMP-2 analysis in connection with ER could be auxiliary for disease diagnosis.

Several authors report a weak or non-significant impact of ER on OS in node-negative populations.

In this work, for the first time, we establish the relevance of a simultaneous evaluation of MMP-2, ER and PR using IHC to predict the onset of metastases and death, i.e., a poor prognosis in breast cancer patients.

\section{Conclusion}

Our results demonstrate the importance of evaluating the relationship between proliferative markers widely used in clinical practice with a possible new marker of metastasis in breast cancer. To summarize, our data show that the IHC analysis of MMP-2 could be included as a new molecular biomarker in breast cancer, improving the prognostic value for metastasis and survival when associated with the traditional ER and PR markers. The clinical importance of this new marker can possibly be extended to create new patient subgroups for better disease characterization.

\section{ACKNOWLEDGMENTS}

We thank the financial support from Brazilian agencies CAPES and CNPq (Process 480738/2010-6 and 479211/2012-4). Particularly, we thank the researchers Emanuel Maltempi de Souza and Fabio de Oliveira Pedrosa for their financial support for the purchase of reagents and other laboratory material during this project.

\section{Resumo}

Pacientes com câncer de mama de pior prognóstico podem ser estimadas por análise imuno-histoquímica de MMP-2 positiva e receptores de estrógeno e progesterona negativos

Introdução: o câncer de mama é a segunda causa de morte no mundo, sendo $90 \%$ dessas mortes decorrentes de metástases. A metaloprotease de matriz 2 (MMP-2) possui atividade de gelatinase capaz de degradar o principal constituinte do microambiente tumoral, o colágeno do tipo IV. Há duas proteínas bem estabelecidas utilizadas como marcadores na prática clínica para o câncer de mama, os receptores de estrógeno (RE) e de progesterona (RP). Embora a presença desses receptores tenha sido associada a um melhor prognóstico, a perda delas pode ocorrer durante a progressão do tumor, com subsequente resistência à terapia hormonal.

Objetivo: analisar a correlação entre as proteínas MMP-2, RE e RP por imuno-histoquímica e estabelecer o processo metastático em tumores de mama primários.

Método: amostras de tumor de mama $(\mathrm{n}=44)$ foram analisadas por imuno-histoquímica para MMP-2, receptor de estrógeno e progesterona.

Resultados: observou-se que $90 \%$ das pacientes que tinham metástases e morreram apresentaram coloração positiva para a MMP-2 ( $\mathrm{p}=0,0082$ para ambos). Usando a análise de Kaplan-Meier, verificou-se que as pacientes RE negativas, também positivas para MMP-2, apresentaram sobrevida livre de doença (SLD) e sobrevida global $(\mathrm{SG})(\mathrm{p}=0,012 \mathrm{e} \mathrm{p}=0,005$, respectivamente) piores quando comparadas às pacientes MMP- 2 negativas. Resultados semelhantes foram encontrados em pacientes RP negativas para SLD $(\mathrm{p}=0,077)$ e SG $(\mathrm{p}=0,038)$.

Conclusão: embora o número de amostras avaliadas tenha sido baixo $(n=44)$, esses dados iniciais permitem inferir que a MMP-2 em combinação com os marcadores já bem estabelecidos poderia ajudar na previsão do surgimento de metástase e morte em pacientes com câncer de mama.

Palavras-chave: neoplasias da mama, MMP-2, imuno-histoquímica, marcador molecular. 


\section{REFERENCES}

1. INCA. Incidência do câncer no Brasil. Estimativa 2014. Rio de Janeiro; 2014

2. Sethi N, Kang Y. Unravelling the complexity of metastasis - Molecular understanding and targeted therapies. Nat Rev Cancer. 2011; 11(10):735-48.

3. Chaffer CL, Weinberg RA. A perspective on cancer cell metastasis. Science. 2011;331(6024):1559-64

4. Nguyen DX, Massagué J. Genetic determinants of cancer metastasis. Nature Rev Genet. 2007; 8(5):341-52

5. Zlotnik A. Chemokines and cancer. Ernst Schering Res Found Workshop. 2004; 45:53-8.

6. Ramos EAS, Grochoski M, Braun-Prado K, Seniski GG, Cavalli IJ, Ribeiro EMSF, et al. Epigenetic changes of CXCR4 and its ligand CXCL12 as prognostic factors for sporadic breast cancer. PloS One. 2011; 6(12):e29461.

7. Hanahan D, Weinberg RA. Hallmarks of cancer: the next generation. Cell. 2011; 144(5):646-74.

8. Stamenkovic I. Matrix metalloproteinases in tumor invasion and metastasis. Semin Cancer Biol. 2000; 10(6):415-33.

9. Artacho-Cordón F, Ríos-Arrabal S, Lara PC, Artacho-Cordón A, Calvente I, Núñez MI. Matrix metalloproteinases: potential therapy to prevent the development of second malignancies after breast radiotherapy. Surg Oncol. 2012; 21(3):e143-51.

10. Clark IM, Swingler TE, Sampieri CL, Edwards DR. The regulation of matrix metalloproteinases and their inhibitors. Int J Biochem Cell Biol. 2008; 40(67):1362-78.

11. Jinga DC, Blidaru A, Condrea I, Ardeleanu C, Dragomir C, Szegli G, et al. MMP9 and MMP- 2 gelatinases and TIMP-1 and TIMP- 2 inhibitors in breast cancer: correlations with prognostic factors. J Cell Mol Med. 2006; 10(2):499-510.

12. Slattery ML, John E, Torres-Mejia G, Stern M, Lundgreen A, Hines L, et al. Matrix metalloproteinase genes are associated with breast cancer risk and survival: the Breast Cancer Health Disparities Study. PloS One. 2013; 8(5):e63165.

13. Väisänen A, Kuvaja P, Kallioinen M, Turpeenniemi-Hujanen T. A prognostic index in skin melanoma through the combination of matrix metalloproteinase-2, Ki67, and p53. Hum Pathol. 2011; 42(8):1103-11.
14. Śmigielski J, Piskorz Ł, Talar-Wojnarowska R, Malecka-Panas E, Jabłoński $\mathrm{S}$, Brocki M. The estimation of metaloproteinases and their inhibitors blood levels in patients with pancreatic tumors. World J Surg Oncol. 2013; 11:137.

15. González-Avila G, Iturria C, Vadillo F, Terán L, Selman M, Pérez-Tamayo R 72-kD (MMP-2) and 92-kD (MMP-9) type IV collagenase production and activity in different histologic types of lung cancer cells. Pathobiology. 1998; 66(1):5-16

16. Kamel H, Abdelazim I, Habib SM, El Shourbagy MA, Ahmed NS. Immunoexpression of matrix metalloproteinase-2 (MMP-2) in malignant ovarian epithelial tumours. J Obstet Gynaecol Can. 2010; 32(6):580-6.

17. Min KW, Kim DH, Do SI, Kim K, Lee HJ, Chae SW, et al. Expression patterns of stromal MMP-2 and tumoural MMP-2 and - 9 are significant prognostic factors in invasive ductal carcinoma of the breast. APMIS 2014; 122(12):1196-206.

18. Hervouet E, Cartron PF, Jouvenot M, Delage-Mourroux R. Epigenetic regulation of estrogen signaling in breast cancer. Epigenetics. 2013; 8(3):237-45.

19. Talvensaari-Mattila A, Paakko P, Turpeenniemi-Hujanen T. Matrix metalloproteinase-2 (MMP-2) is associated with survival in breast carcinoma. Br J Cancer. 2003; 89(7):1270-5.

20. Kaplan EL, Meier P. Nonparametric estimation from incomplete observations. J Am Stat Assoc. 1958; 53(282):457-81.

21. Razandi M, Pedram A, Park ST, Levin ER. Proximal events in signaling by plasma membrane estrogen receptors. J Biol Chem. 2003; 278(4):2701-12.

22. Filardo EJ, Quinn JA, Frackelton AR Jr, Bland KI. Estrogen action via the G protein-coupled receptor, GPR30: stimulation of adenylyl cyclase and cAMPmediated attenuation of the epidermal growth factor receptor-to-MAPK signaling axis. Mol Endocrinol. 2002; 16(1):70-84.

23. Struse K, Audretsch W, Rezai M, Pott G, Bojar H. The estrogen receptor paradox in breast cancer: association of high receptor concentrations with reduced overall survival. Breast J. 2000; 6(2):115-25.

24. Ranogajec I, Jakic-Razumovic J, Puzovic V, Gabrilovac J. Prognostic value of matrix metalloproteinase-2 (MMP-2), matrix metalloproteinase-9 (MMP9) and aminopeptidase N/CD13 in breast cancer patients. Med Oncol. 2012; 29(2):561-9. 